\title{
EFEKTIVITAS PEMBELAJARAN KELOMPOK PRODUKTIF TEKNIK KOMPUTER DAN INFORMATIKA YANG MENERAPKAN KTSP SMKN
}

\author{
Achmad Firdaus \\ SMK Negeri 3 Amuntai Hulu Sungai Utara Kalimantan Selatan \\ Achmad.firdaus.spd@gmail.com
}

\begin{abstract}
Abtrak: Efektivitas Pembelajaran Kelompok Produktif Teknik Komputer dan Informatika yang Menerapkan KTSP SMKN. Penelitian ini bertujuan untuk mendeskripsikan efektivitas pembelajaran kelompok produktif program studi teknik komputer dan informatika yang menerapkan KTSP pada SMK Negeri ditinjau dari: 1) kelengkapan dan kesesuaian perangkat perencanaan pembelajaran; 2) proses pembelajaran, 3) penilaian pembelajaran; 4) respon peserta didik terhadap kegiatan pembelajaran; dan 5) hasil belajar peserta didik. Jenis penelitian adalah penelitian survei dengan populasi penelitian dua SMK Negeri di Kabupaten Hulu Sungai Utara. Berdasarkan hasil analisis dapat disimpulkan bahwa pembelajaran kelompok produktif teknik komputer dan informatika yang menerapkan KTSP sudah efektif. Hal ini juga dilihat dari aspek berikut ini. 1) Hasil telaah kelengkapan dan kesesuaian perangkat perencanaan pembelajaran kelompok produktif baik silabus maupun RPP yang dikembangkan oleh guru berada pada kategori baik. Penyusunan dan pengembangan perangkat perencanaan tersebut sudah mengacu pada standar isi, standar kompetensi lulusan dan sudah sesuai dengan langkah-langkah maupun format KTSP. Namun masih dapat ditingkatkan khususnya pada aspek pengidentifikasian materi pembelajaran, perumusan pengalaman belajar, perumusan indikator pencapaian kompetensi, dan bentuk penilaian yang akan digunakan. 2) Hasil observasi proses pembelajaran berada pada kategori baik. Dengan demikian, proses pembelajaran dapat dikatakan telah sesuai dengan langkah-langkah yang ada pada standar proses. Namun masih dapat ditingkatkan pada aspek penerapan materi terhadap kehidupan sehari-hari, menanggapi pertanyaan peserta didik, dan pembuatan rangkuman materi pembelajaran. 3) Hasil observasi penilaian pembelajaran berada pada kategori tidak baik, karena penilaian yang dilakukan oleh guru hanya pada aspek kognitif. Dengan demikian perlu adanya peningkatan pada prinsip-prinsip penilaian dan pelaksanaan penilaian pada aspek afektif dan psikomotor. 4) Respon peserta didik berada pada kategori baik hal ini mengindikasikan bahwa kegiatan pembelajaran yang dikelola oleh guru mendapat respon yang positif dari peserta didik. 5) Hasil belajar peserta didik dapat dikatakan efektif dan berhasil dengan prosentase ketuntasan belajar sebesar 96,00\%.
\end{abstract}

Kata kunci: efektivitas, perencanaan, proses, penilaian pembelajaran 


\title{
LEARNING EFFECTIVENESS OF THE COMPUTER ENGINEERING AND INFORMATICS PRODUCTIVE GROUP APPLYING THE SCHOOL-BASED CURRICULUM IN STATE VOCATIONAL HIGH SCHOOL
}

\begin{abstract}
Learning Effectiveness of The Computer Engineering and Informatics Productive Group Applying The School-Based Curriculum in State Vocational High School. This study aims to describe the learning effectiveness of the productive group in the computer engineering and informatics study program applying the School-Based Curriculum in state vocational high schools (SVHSs) in terms of: 1) the completeness and appropriateness of the learning kits, 2) the learning process, 3) the learning assessment, 4) the students' responses to the learning activities, and 5) the students' learning outcomes. This was a survey study with a population comprising two SVHSs in the regency of Hulu Sungai Utara. Based on the results of the analysis, it can be concluded that learning in the computer engineering and informatics productive group applying the School-Based Curriculum has been effective. It can be seen from the following aspects. 1) The results of the review of the completeness and appropriateness of the productive learning kits consisting of syllabuses and lesson plans developed by teachers are in the good category. The formulation and development of the planning kits already refer to the content standards, competency standards and are in accordance with the steps and School-Based Curriculum format. However, the aspect of identifying learning materials, the learning experience formulation, the formulation of competency achievement indicators, and assessment forms need to be improved. 2) The results of observations on the learning process are in the good category. Thus, the learning process is already in conformity with the process standard. However, the aspects of applying the materials from daily life, responding to the students' questions, and making a learning material summary need to be improved. 3) The results observations on the learning assessment are in the poor category, because the assessment carried out by teachers focuses only on the cognitive aspects. Thus, the principles of assessment and implementation of assessment in the affective and psychomotor aspects need to be improved. 4) The students' responses are in the good category. This indicates that the learning activities managed by teachers get positive responses from the students. 5) The students' learning outcomes are relatively effective and successful with a percentage of learning mastery of 96,00\%.
\end{abstract}

Keywords: effectiveness, planning, process, assessment of learning 


\section{PENDAHULUAN}

Keberhasilan pembangunan nasional Indonesia di segala bidang akan sangat bergantung pada kualitas sumber daya manusia dalam mengoptimalkan dan memaksimalkan perkembangan seluruh dimensi pembangunan. Upaya tersebut dapat ditempuh melalui pendidikan, baik melalui pendidikan formal maupun non-formal. Satuan pendidikan pada jenjang pendidikan formal yang bertujuan menyiapkan lulusannya terutama untuk memiliki keunggulan di dunia kerja adalah Sekolah Menengah Kejuruan (SMK).

Pada lampiran Permendiknas Nomor 22 Tahun 2006 tentang Standar Isi menjelaskan bahwa pendidikan kejuruan bertujuan untuk meningkatkan kecerdasan, pengetahuan, kepribadian, akhlak mulia, serta keterampilan peserta didik untuk hidup mandiri dan mengikuti pendidikan lebih lanjut sesuai dengan program kejuruannya. Agar dapat bekerja secara efektif dan efisien serta mengembangkan keahlian dan keterampilan, mereka harus memiliki stamina yang tinggi, menguasai bidang keahliannya dan dasar-dasar ilmu pengetahuan dan teknologi, memiliki etos kerja yang tinggi, dan mampu berkomunikasi sesuai dengan tuntutan pekerjaannya, serta memiliki kemampuan mengembangkan diri.

Meningkatnya persaingan global yang terjadi saat ini mengharuskan SMK berkembang mengikuti arah perkembangan dunia kerja, sehingga SMK perlu melakukan penyesuaian dengan membuka kompetensi keahlian baru atau mempertajam kompetensi keahlian yang sudah ada dengan meningkatkan kualitas pembelajaran dan mempertimbangkan relevansinya terhadap tuntutan dunia usaha dan dunia industri (DU/DI).

SMK Teknik komputer dan informatika merupakan program studi keahlian yang banyak diminati oleh masyarakat. Berbagai alasan bermunculan antara lain beranggapan dapat menghasilkan tenaga kerja yang siap pakai, prospek kerja lulusannya bagus, tidak menguasai komputer identik dengan buta huruf, minat, prestise atau kebanggaan. Melihat berbagai alasan yang bermunculan di masyarakat, diharapkan pihak sekolah untuk selalu menigkatkan mutu pendidikannya.

Salah satu komponen penting untuk meningkatkan mutu sekolah adalah dengan adanya kurikulum yang bermutu. Kurikulum merupakan komponen sistem pendidikan yang paling rentan terhadap perubahan. Paling tidak ada tiga faktor yang membuat kurikulum harus selalu dirubah atau diperbaharui. Pertama, karena adanya perubahan filosofi tentang manusia dan pendidikan, khususnya mengenai hakikat kebutuhan peserta didik terhadap pendidikan/pembelajaran. Kedua, cara karena cepatnya perkembangan ilmu dan teknologi, sehingga subject matter yang harus disampaikan kepada peserta didik pun semakin banyak dan beragam. Ketiga, adanya perubahan masyarakat, baik secara sosial, politik, ekonomi, maupun daya dukung lingkungan alam, baik pada tingkat lokal maupun global.

Keberhasilan atau kegagalan implementasi sebuah kurikulum disekolah terletak pada guru dan kepala sekolah, karena dua figur tersebut merupakan kunci yang menentukan dan menggerakkan berbagai komponen dan dimensi sekolah yang lain. Tanpa mengurangi arti penting tenaga kependidikan 
yang lain, baik buruknya perangkat sekolah sangat ditentukan oleh kualitas guru dan kepala sekolah. Dengan KTSP guru dituntut membuktikan profesionalismenya untuk mampu menterjemahkan dan mengembangkan Standar Kompetensi dan Kompetensi Dasar dan menuangkannya ke dalam silabus dan rencana perangkat pembelajaran (RPP) serta mengaktualisasikan di dalam pembelajaran.

Berdasarkan latar belakang di atas dapat diidentifikasi beberapa permasalahan antara lain. 1) Silabus \& RPP belum tersusun dengan baik dan proses pembelajaran belum terlaksana sesuai dengan standar proses. 2) Sebagian guru belum menyusun bahan ajar yang dikemas secara utuh dan sistematis berupa modul pembelajaran. 3) Sebagian guru belum melaksanakan sistem penilaian sesuai tuntutan KTSP. 4) Kurangnya motivasi peserta didik karena tidak mengetahui keutamaan apa yang terkandung dalam materi pembelajaran yang sedang disampaikan oleh guru. 5) Kurangnya motivasi peserta didik karena tidak mengetahui keutamaan apa yang terkandung dalam materi pembelajaran yang sedang disampaikan oleh guru.

Melihat permasalahan di atas maka penelitian ini dibatasi pada: 1) penyusunan perangkat perencanaan pembelajaran yang meliputi silabus dan RPP; 2) proses pembelajaran kelompok produktif; 3) jenis dan bentuk penilaian yang digunakan oleh guru. Dengan demikian rumusan permasalahan yang akan diangkat dalam penelitian ini sebagai berikut: 1) bagaimanakah kelengkapan dan kesesuaian perangkat perencanaan pembelajaran yang dibuat guru kelompok produktif program studi Teknik Komputer dan Informatika yang menerapkan KTSP pada SMK Negeri di Kabupaten Hulu Sungai Utara; 2) bagaimanakah implementasi standar proses terhadap proses pembelajaran kelompok produktif program studi Teknik Komputer dan Informatika yang menerapkan KTSP pada SMK Negeri di Kabupaten Hulu Sungai Utara; 3) bagaimanakah penggunaan jenis dan bentuk penilaian guru terhadap hasil belajar peserta didik kelompok produktif program studi Teknik Komputer dan Informatika yang menerapkan KTSP pada SMK Negeri di Kabupaten Hulu Sungai Utara.

Penelitian ini bertujuan untuk memperoleh gambaran mengenai: 1) kelengkapan dan kesesuaian perangkat perencanaan pembelajaran yang disusun oleh guru kelompok produktif program studi Teknik Komputer dan Informatika yang menerapkan KTSP pada SMK Negeri di Kabupaten Hulu Sungai Utara; 2) proses pembelajaran kelompok produktif program studi Teknik Komputer dan Informatika yang menerapkan KTSP pada SMK Negeri di Kabupaten Hulu Sungai Utara; 3) jenis dan bentuk penilaian yang digunakan oleh guru kelompok produktif program studi Teknik Komputer dan Informatika yang menerapkan KTSP pada SMK Negeri di Kabupaten Hulu Sungai Utara.

Null (2011: 1) berpendapat bahwa:

Curriculum is the heart of education. The reason is twofold. First, curriculum is about what should be taught. Second, it combines thought, action, and purpose. Curriculum, however, is a specific, tangible subject that is always tied to decision making within institutions, whether they are schools, churches, nonprofit agencies, or governmental programs. 
Berdasarkan pendapat di atas, kurikulum merupakan jantung dari sebuah pendidikan. Ada dua alasan yang mendasari pengertian tersebut. Pertama, kurikulum berhubungan dengan tentang apa yang harus diajarkan. Kedua, penggabungan antara pikiran, tindakan, dan tujuan. Kurikulum merupakan suatu hal yang spesifik, subyek nyata yang selalu terkait dengan pengambilan keputusan di dalam lembaga-lembaga, apakah itu di sekolah, gereja, lembaga nirlaba, maupun program pemerintah. Sedangkan kompetensi menurut McAshan (Enco Mulyasa, 2010: 38) adalah

...is a knowledge, skills, and abilities or capabilities that a person achieves, which become part of his or her being to the exent he or she can satisfactorily perform particular cognitive, afective, and psychomotor behaviors.

Kompetensi diartikan sebagai pengetahuan, keterampilan, dan kemampuan yang dikuasai oleh seseorang yang telah menjadi bagian dari dirinya, sehingga ia dapat melakukan perilakuperilaku kognitif, afektif dan psikomotorik dengan sebaik-baiknya.

KTSP pada dasarnya merupakan salah satu jenis dari model konsep kurikulum teknologis. Meskipun model kurikulum teknologis menjadi tulang punggung pengembangan KTSP, tapi tidak berarti nilai esensial dari model kurikulum lainnya diabaikan. Karakter yang ada pada model lainnya tetap ada, hanya tidak dominan, karena dalam realitasnya model-model tersebut saling melengkapi. Hal ini bisa dilihat dalam prinsipprinsip pengembangan KTSP dan acuan operasional penyususunan KTSP yang dikembangkan Badan Standar Nasional Pendidikan (BSNP).
Kata "pembelajaran" adalah terjemahan dari "instruction", yang banyak dipakai dalam dunia pendidikan di Amerika Serikat. Istilah ini banyak dipengaruhi oleh aliran psikologi kognitif-wholistik, yang menempatkan peserta didik sebagai sumber dari kegiatan. Hal ini seperti yang diungkapkan Johnson (Oliva, 2005: 7), yang menyatakan

...defined instruction as the interaction between a teaching agent and one or more individuals intending to learn.

Yang mengandung arti interaksi antara agen pembelajaran (guru) dan satu atau lebih individu yang berniat untuk belajar. Russell (2012: 58),

The methods and processes actually used to change students behaviour are called instruction.

Pembelajaran merupakan metode dan proses yang digunakan untuk merubah perilaku peserta didik.

Undang-Undang Nomor 20 Tahun 2003 tentang Sistem Pendidikan Nasional pasal 1 ayat (20) menyatakan bahwa "pembelajaran adalah proses interaksi antara peserta didik dengan pendidik dan sumber belajar pada suatu lingkungan belajar". Prinsip utama pembelajaran adalah proses keterlibatan seluruh atau sebagian besar potensi diri siswa (fisik dan non fisik) dan kebermaknaannya bagi diri dan kehidupannya saat ini dan di masa yang akan datang.

Pavlova (2009: 7) mengemukakan tentang pendidikan kejuruan secara umum adalah sebagai berikut.

Traditionally, direct preparation for work was the main goal of vocational education. It was perceived as providing specific training that was reproductive and based on teachers' instruction, with the intention to develop understanding of a particular industry, comprising the specific skills or tricks of the trade. Students' motivation was 
seen to be engendered by the economic benefits to them, in the future.

Dari pengertian di atas menyebutkan bahwa, tujuan utama dari pendidikan kejuruan adalah persiapan untuk dapat langsung bekerja. Dipandang sebagai penyediaan pelatihan khusus yang reproduktif dan berbasis pada instruksi guru. dengan tujuan untuk mengembangkan pemahaman tentang industri tertentu, yang terdiri dari keterampilan khusus atau trik kejuruan. Motivasi siswa terlihat dari manfaat ekonomi yang ditimbulkan kepada mereka, di masa depan.

Senada dengan pandangan sebelumnya, di dalam lampiran Permendiknas Nomor 22 Tahun 2006 disebutkan bahwa "pendidikan kejuruan bertujuan untuk meningkatkan kecerdasan, pengetahuan, kepribadian, akhlak mulia, serta keterampilan peserta didik untuk hidup mandiri dan mengikuti pendidikan lebih lanjut sesuai dengan program kejuruannya. Agar dapat bekerja secara efektif dan efisien serta mengembangkan keahlian dan keterampilan, mereka harus memiliki stamina yang tinggi, menguasai bidang keahliannya dan dasar-dasar ilmu pengetahuan dan teknologi, memiliki etos kerja yang tinggi, dan mampu berkomunikasi sesuai dengan tuntutan pekerjaannya, serta memiliki kemampuan mengembangkan diri.

\section{METODE}

Penelitian ini termasuk dalam jenis penelitian survei dengan pendekatan deskriptif kuantitatif. Penelitian survei merupakan penelitian yang dilakukan dengan mengumpulkan data yang ada di tempat yang diteliti secara alamiah tanpa memberikan perlakuan, manipulasi atau pengubahan pada variabel-variabel bebas, tetapi menggambarkan suatu kondisi apa adanya

Teknik pengumpulan data dan informasi yang digunakan untuk mengungkapkan kegiatan pembelajaran kelompok produktif teknik komputer dan informatika yang menerapkan KTSP adalah melalui lembar telaah perangkat perencanaan pembelajaran, observasi proses pembelajaran, observasi penilaian pembelajaran, dan angket.

Salah satu persyaratan yang harus dipenuhi oleh instrumen (alat ukur) adalah validitas. Validitas alat ukur berkaitan dengan sejauhmana alat ukur mampu mengukur apa yang seharusnya diukur. Validitas konstruk menunjuk sejauhmana suatu instrumen mampu mengukur pengertian-pengertian yang terkandung dalam materi yang akan diukur. Jadi tujuan pengujian validitas konstruk adalah untuk mendapatkan bukti tentang sejauhmana hasil pengukuran memberikan konstruk variabel yang diukur.

Apabila alat pengukur telah memiliki validitas konstruk berarti semua item (pertanyaan/pernyataan) yang ada dalam alat pengukur itu mengukur konsep yang ingin diukur. Untuk menguji eksistensi atau mencari konstruk-konstruk dalam variabel digunakanlah analisis faktor. Secara esensial, analisis faktor merupakan suatu teknik analisa penyaring untuk menganalisis saling hubungan di antara butirbutir instrumen, dalam mengembangkan suatu tes yang sifatnya psikologis maka analisis faktor sangat relevan untuk menguji kesahihan konstruk.

Sebelum digunakan pada penelitian yang sesungguhnya, terlebih dahulu dilakukan uji coba terhadap instrumen atau alat pengumpul 
data dengan tujuan untuk mengetahui kualitas instrumen yang meliputi sekurang-kurangnya validitas dan reliabilitas instrumen. Instrumen yang digunakan untuk uji coba adalah instrumen C yaitu angket respon peserta didik terhadap kegiatan pembelajaran.

Item pada instrumen $\mathrm{C}$ berjumlah 16 pernyataan/pertanyaan yang diuji cobakan kepada peserta didik berjumlah sebanyak 30 orang. Semua proses analisis faktor digunakan bantuan paket program SPSS for windows version 17.0. Hasil komputasi pada Tabel 3 menunjukkan Kaiser Meyer Olkin mengenai measure of sampling adequacy (KMO MSA) sebesar 0,701 dengan signifikansi sebesar 0,000. Angka 0,701 berada di atas 0,5 dan signifikansi pada 0,000 , jadi dengan hasil tersebut adalah baik dan dapat dianalisis lebih lanjut. Dari uji Bartleet untuk test of sphericity diperoleh Chi Square sebesar 213.527 dengan derajat kebebasan 120 dan signifikansi pada 0,000 yang berarti matriks korelasi bukan merupakan matriks identitas sehingga dapat digunakan analisis faktor.

Tabel 1. KMO and Bartlett's Test Uji Coba Instrumen C

\begin{tabular}{|c|c|c|}
\hline \multicolumn{3}{|c|}{ KMO and Bartlett's Test } \\
\hline \multicolumn{2}{|c|}{ Kaiser-Meyer-Olkin Measure of Sampling Adequacy. } & 0,701 \\
\hline \multirow[t]{3}{*}{ Bartlett's Test of Sphericity } & Approx. Chi-Square & 213,527 \\
\hline & df & 120 \\
\hline & Sig. & 0,000 \\
\hline
\end{tabular}

Harga MSA Pada Tabel anti image correlation dari keenambelas item berada diatas 0,50 yang mengindikasikan bahwa tidak ada item yang gugur. Kemudian pada Tabel total variance explained dari 16 item yang dimasukkan ke dalam analisis faktor didapatkan nilai akar karakteristik (eigen values) diatas 1 $(\geq 1)$ ada sebanyak 5 faktor, sudah sesuai dengan yang diestimasikan.

Dengan demikian dapat disimpulkan bahwa instrumen respon peserta didik tersebut adalah valid ditinjau dari validitas konstruk. Selain itu adanya varians muatan faktor yang dapat menjelaskan varians respon peserta didik terhadap kegiatan pembelajaran, muatan secara kumulatif kelima faktor tersebut adalah sebesar $71,922 \%$ varians.
Selanjutnya tampilan screen plot merupakan penjelasan untuk Tabel total variance explained dalam bentuk grafik. Diagram scree plot menunjukkan bagaimana kecenderungan penurunan nilai eigen (eigenvalues) yang dipakai untuk menentukan secara subjektif banyaknya faktor yang dipakai.

Dengan demikian dapat disimpulkan bahwa pada ujicoba instrumen $\mathrm{C}$ respon peserta didik terhadap kegiatan pembelajaran yang dikembangkan telah memiliki validitas konstruk yang baik. Untuk koefisien reliabiliatas digunakan koefisien alpha dan didapat koefisien sebesar 0,869, sehingga dapat dikatakan bahwa item pada instrumen tersebut memiliki konsistensi internal yang baik, mengingat $\alpha>$ 
0,60 maka dikatakan instrumen penelitian reliabel.

Tabel 2. Reliability Statistics Uji Coba Instrumen C

\begin{tabular}{cc}
\hline \hline \multicolumn{2}{c}{ Reliability Statistics } \\
\hline \hline Cronbach's Alpha & N of Items \\
0,869 & 16 \\
\hline
\end{tabular}

Data yang diperoleh di lapangan dianalisa dengan menggunakan teknik deskriptif kuantitatif, yaitu dengan mendeskripsikan dan memaknai data dari masing-masing komponen/aspek yang dievaluasi. Data yang sudah terkumpul, diolah atau dianalisa dengan tahap-tahap sebagai berikut: (1) menghitung skor (tertinggi dan terendah) pada masingmasing komponen; (2) menghitung rerata skor masing-masing komponen atau mean ideal ( $\overline{\mathrm{X}}$ ); (3) menentukan simpangan baku ideal (SBx); dan (4) menentukan tingkat kecenderungan. Perhitungan mean ideal, simpangan baku ideal yaitu:

Mean ideal/rerata $(\overline{\mathrm{X}})=\frac{1}{2} \mathrm{x}$ (skor tertinggi ideal + skor terendah ideal)

Simpangan baku ideal $(\mathrm{SBx})=\frac{1}{6} \mathrm{x}$ (skor tertinggi ideal - skor terendah ideal)

Tingkat kecenderungan dibagi dalam empat kategori seperti tampak pada tabel 3 . Tingkat kecenderungan ini menjadi kriteria analisis selanjutnya. Analisis keberhasilan pembelajaran kelompok produktif teknik komputer dan informatika dapat dilihat dari hasil belajar peserta didik. Pelaksanaan pembelajaran dikatakan berhasil dan efektif jika $75 \%$ peserta didik mencapai ketuntasan belajarnya.

Tabel 3. Kategori Penilaian

\begin{tabular}{cc}
\hline \hline Rentang skor & Interpretasi \\
\hline \hline $\mathrm{X} \geq \overline{\mathrm{X}}+1 . \mathrm{SBx}$ & Sangat baik \\
$\overline{\mathrm{X}}+1 . \mathrm{SBx}>\mathrm{X} \geq \overline{\mathrm{X}}$ & Baik \\
$\overline{\mathrm{X}}>\mathrm{X} \geq \overline{\mathrm{X}}-1 . \mathrm{SBx}$ & Tidak baik \\
$\mathrm{X}<\overline{\mathrm{X}}-1 . \mathrm{SBx}$ & Sangat tidak baik \\
\hline
\end{tabular}

Sumber: diadaptasi dari Djemari Mardapi (2008: 123)

Keterangan:

X : Skor Responden

$\overline{\mathrm{X}} \quad$ : Rerata Skor Keseluruhan

SBx : Simpangan Baku Ideal Skor

Keseluruhan

\section{HASIL PENELITIAN}

Analisis hasil dokumentasi perencanaan pembelajaran untuk keempat kompetensi keahlian di SMK Negeri 1 Amuntai dan SMK Negeri 3 Amuntai pada menunjukkan bahwa dokumen perencanaan pembelajaran kelompok 
produktif secara keseluruhan berada pada kategori baik dengan perolehan skor rerata sebesar 46,21. Dari data tersebut menunjukkan bahwa ada dokumen perencanaan pembelajaran yang dibuat oleh guru produktif pada masing- masing satuan pendidikan, sebagai perencanaan dan persiapan pembelajaran.

Berikut gambaran distribusi frekuensi dan kategori ideal untuk dokumen perencanaan pembelajaran.

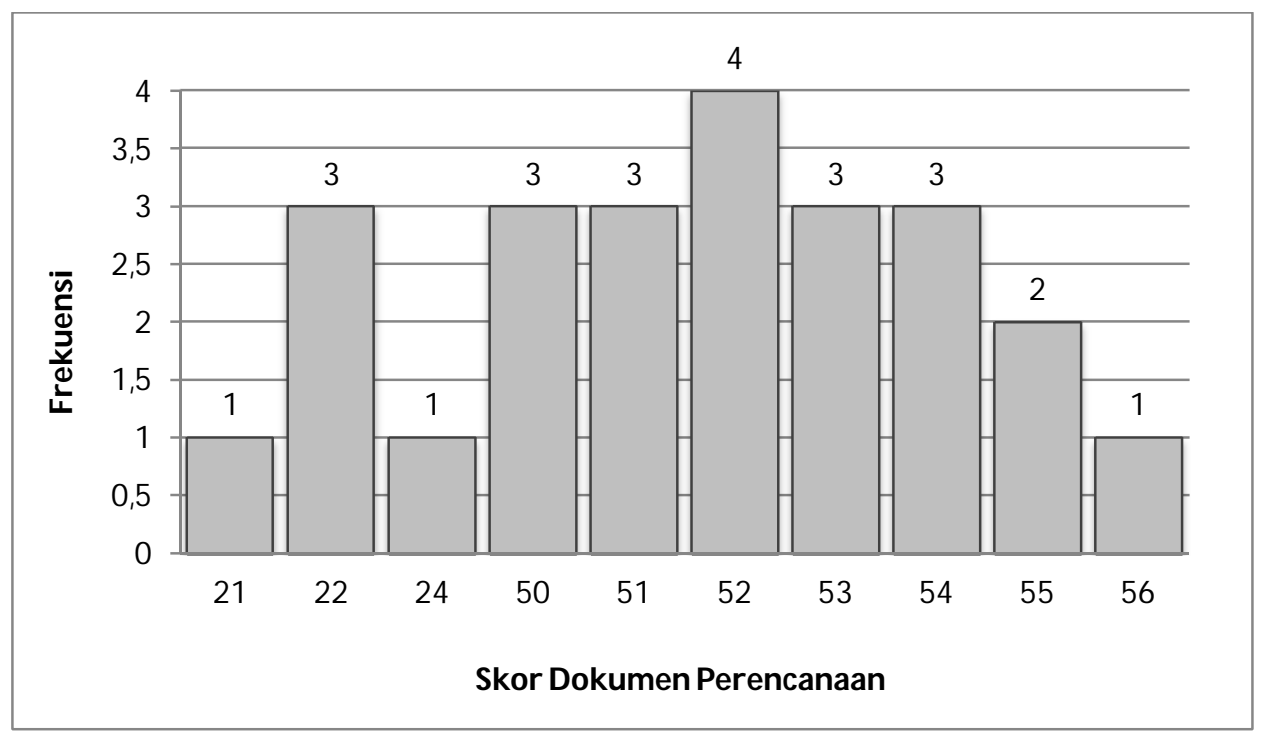

Gambar 1. Histogram Distribusi Frekuensi Skor Dokumen Perencanaan Pembelajaran

Berdasarkan data distribusi frekuensi pada gambar 1 di atas, skor dokumen perencanaan pembelajaran dapat dikelompokkan dalam kategori berikut.

Tabel 4. Kategori Ideal Skor Dokumen Perencanaan Pembelajaran

\begin{tabular}{ccccc}
\hline \hline No & Kategori & Skor & Frek. Absolut & Frek. Relatif (\%) \\
\hline \hline 1 & Sangat Baik & $\mathrm{X} \geq 48$ & 19 & 79,17 \\
2 & Baik & $48>\mathrm{X} \geq 40$ & - & 0 \\
3 & Tidak Baik & $40>\mathrm{X} \geq 32$ & - & 0 \\
4 & Sangat Tidak Baik & $\mathrm{X}<32$ & 5 & 20,83 \\
\hline & Jumlah & 24 & 100 \\
\hline
\end{tabular}

Berdasarkan tabel 4, menunjukkan bahwa jumlah dokumen perencanaan pembelajaran kelompok produktif yang berkategori sangat baik adalah 19 dokumen perencanaan $(79 \%)$ dan 5 dokumen perencanaan $(21 \%)$ berkategori sangat tidak baik. Sementara tidak ada satupun dokumen perencanaan pembelajaran $(0 \%)$ yang memiliki skor berkategori baik dan tidak baik. 


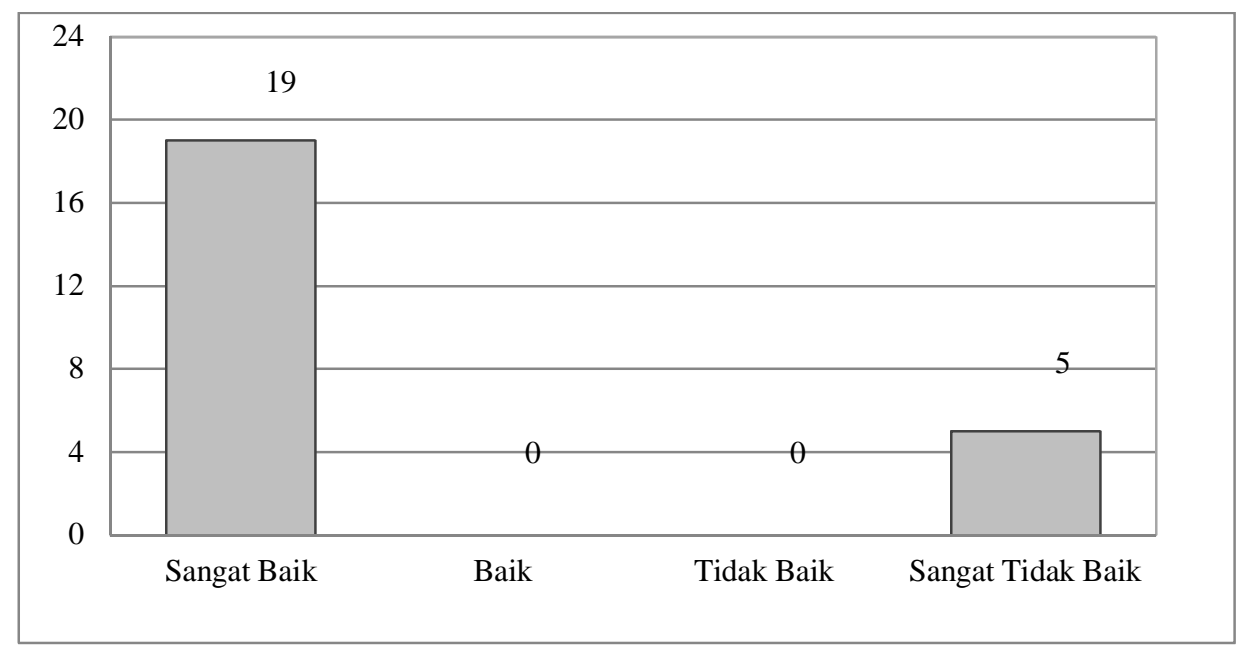

Gambar 2. Histogram Proporsi Skor Dokumen Perencanaan Pembelajaran di SMKN 1 Amuntai dan SMKN 3 Amuntai

Analisis data hasil observasi proses pembelajaran untuk keempat kompetensi keahlian di SMK Negeri 1 Amuntai dan SMK Negeri 3 Amuntai secara keseluruhan berada pada kategori baik dengan perolehan skor rerata sebesar 50,33. Hal ini menunjukkan bahwa proses pembelajaran dari keempat kompetensi keahlian dapat dikatakan telah sesuai dengan rencana yang telah dibuat.

Berikut gambaran distribusi frekuensi dan kategori ideal untuk observasi proses pembelajaran.

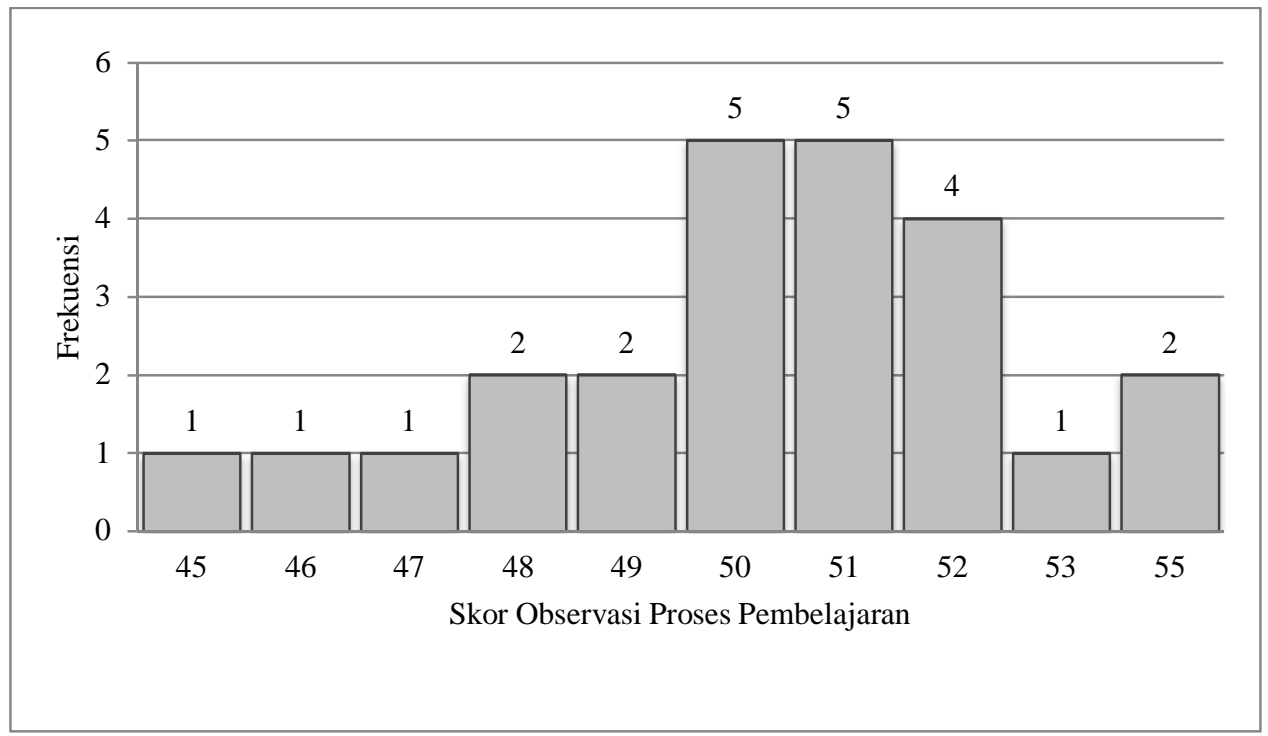

Gambar 3. Histogram Distribusi Frekuensi Skor Observasi Proses Pembelajaran

Berdasarkan data distribusi frekuensi pada gambar 3, skor observasi proses pembelajaran dapat dikelompokkan dalam kategori berikut. 
Tabel 5. Kategori Ideal Skor Observasi Proses Pembelajaran

\begin{tabular}{ccccc}
\hline \hline No & Kategori & Skor & Frek. Absolut & Frek. Relatif $(\%)$ \\
\hline \hline 1 & Sangat Baik & $\mathrm{X} \geq 51$ & 12 & 50,00 \\
2 & Baik & $51>\mathrm{X} \geq 42,50$ & 12 & 50,00 \\
3 & Tidak Baik & $42,50>\mathrm{X} \geq 34$ & - & 0 \\
4 & Sangat Tidak Baik & $\mathrm{X}<34$ & - & 0 \\
\hline Jumlah & & 24 & 100 \\
\hline
\end{tabular}

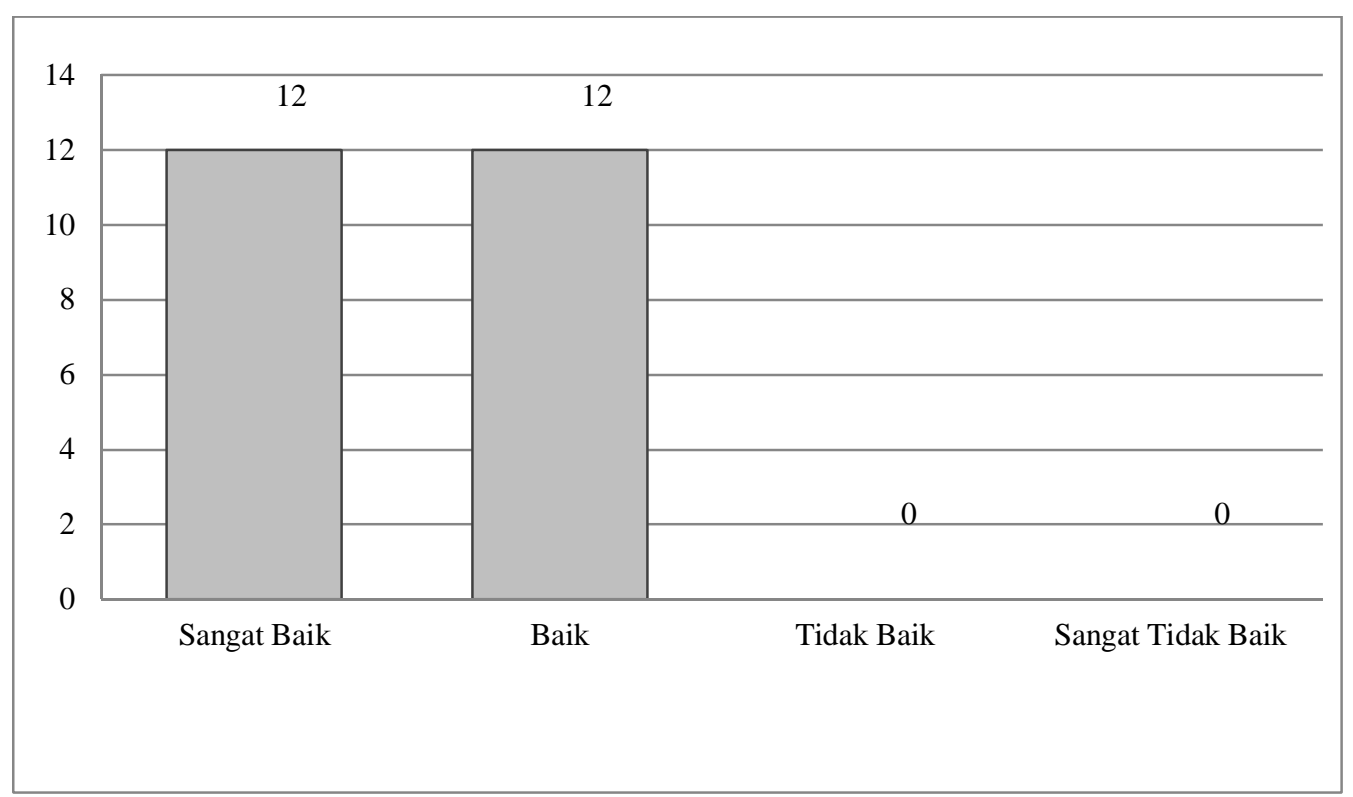

Gambar 4. Histogram Proporsi Skor Observasi Proses Pembelajaran di SMKN 1 Amuntai dan SMKN 3 Amuntai

Berdasarkan data pada tabel 5, menunjukkan bahwa proporsi skor hasil observasi proses pembelajaran kelompok produktif yang berkategori sangat baik adalah 12 mata pelajaran $(50 \%)$ dan 12 mata pelajaran (50\%) berkategori baik. Sementara tidak ada satupun hasil observasi proses pembelajaran (0\%) yang memiliki skor berkategori tidak baik dan sangat tidak baik.

Analisis data hasil observasi penilaian pembelajaran untuk keempat kompetensi keahlian di SMK Negeri 1 Amuntai dan SMK
Negeri 3 Amuntai secara keseluruhan berada pada kategori tidak baik dengan perolehan skor rerata sebesar 17,04. Dengan demikian menunjukkan bahwa guru produktif kurang memperhatikan penilaian proses pembelajaran. Penilaian pada akhir pembelajaran terkadang dilakukan untuk menilai aspek kognitif peserta didik, seperti tes lisan, tes tertulis, dan penugasan.

Berikut gambaran distribusi frekuensi dan kategori ideal untuk observasi penilaian pembelajaran. 


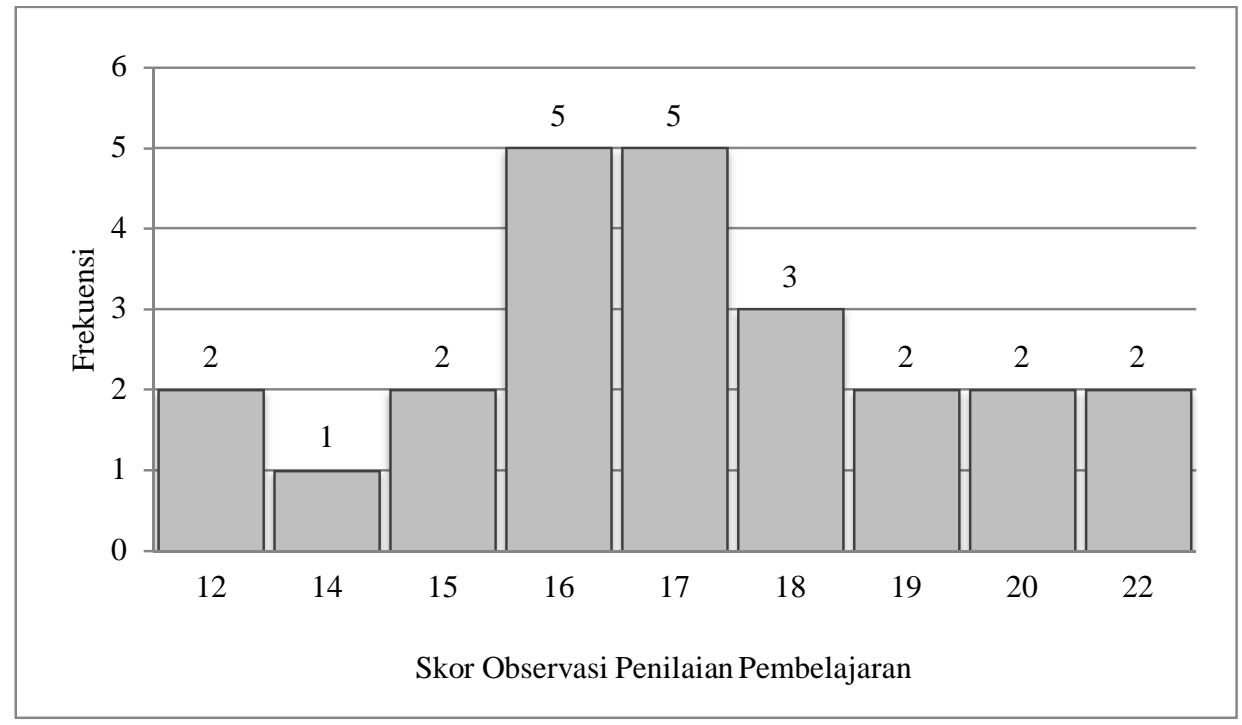

Gambar 5. Histogram Distribusi Frekuensi Skor Observasi Penilaian Pembelajaran

Berdasarkan data distribusi frekuensi pada gambar 5 di atas, skor observasi penilaian pembelajaran dapat dikelompokkan dalam kategori berikut.

Tabel 6. Kategori Ideal Skor Observasi Penilaian Pembelajaran

\begin{tabular}{|c|c|c|c|c|}
\hline No & Kategori & Skor & Frek. Absolut & Frek. Relatif (\%) \\
\hline 1 & Sangat Baik & $X \geq 21$ & 2 & 8,33 \\
\hline 2 & Baik & $21>X \geq 17,50$ & 7 & 29,17 \\
\hline 3 & Tidak Baik & $17,50>X \geq 14$ & 13 & 54,17 \\
\hline 4 & Sangat Tidak Baik & $X<14$ & 2 & 8,33 \\
\hline \multicolumn{3}{|c|}{ Jumlah } & 24 & 100 \\
\hline
\end{tabular}

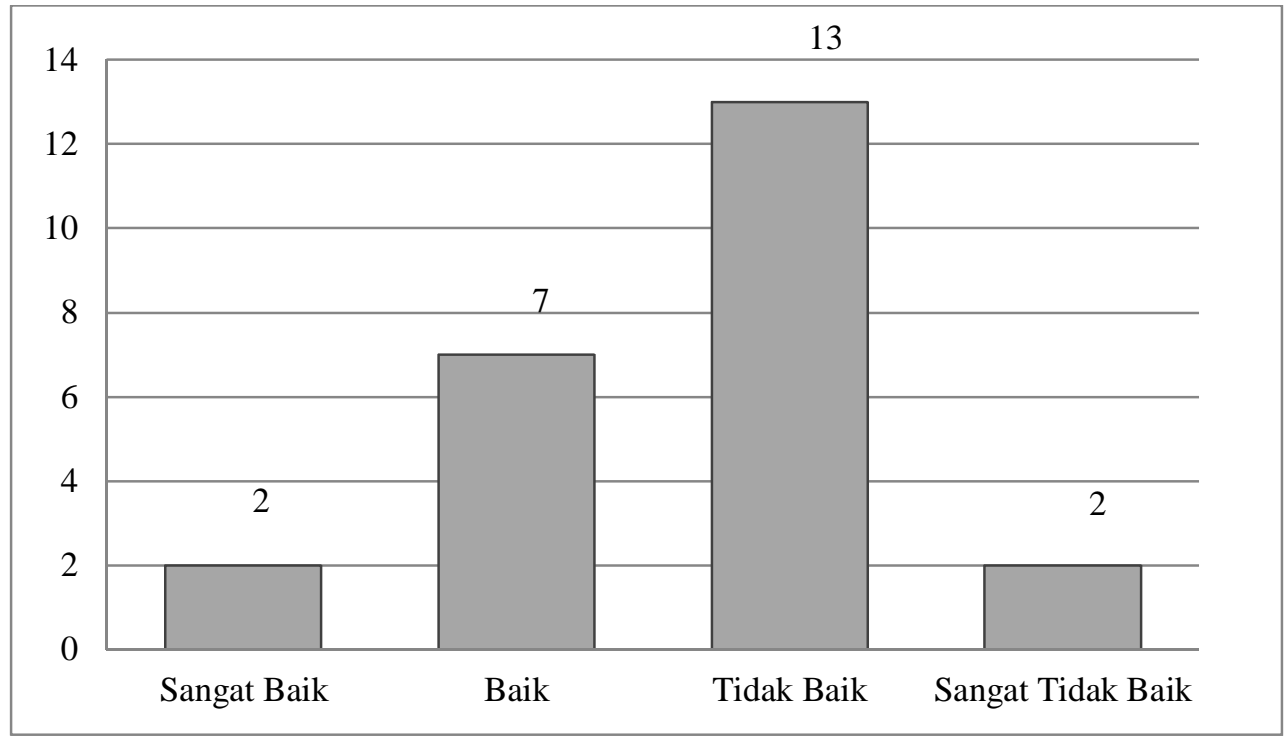

Gambar 6. Histogram Proporsi Skor Observasi Penilaian Pembelajaran di SMKN 1 Amuntai dan SMKN 3 Amuntai 
Berdasarkan tabel 6, menunjukkan bahwa proporsi skor hasil observasi penilaian pembelajaran kelompok produktif yang berkategori sangat baik adalah 2 mata pelajaran $(8,33 \%), 7$ mata pelajaran $(29,17 \%)$ berkategori baik, 13 mata pelajaran $(54,17 \%)$ berkategori tidak baik, dan 2 mata pelajaran $(8,33 \%)$ berkategori sangat tidak baik.
Rangkuman skor hasil angket respon peserta didik terhadap kegiatan pembelajaran kelompok produktif pada keempat kompetensi keahlian di SMK Negeri 1 Amuntai dan SMK Negeri 3 Amuntai disajikan pada tabel berikut.

Tabel 7. Rangkuman Skor Hasil Angket Respon Peserta Didik terhadap Kegiatan Pembelajaran

\begin{tabular}{ccccc}
\hline \hline No & Sekolah & $\begin{array}{c}\text { Kompetensi } \\
\text { Keahlian }\end{array}$ & \multicolumn{2}{c}{ Skor } \\
\hline \hline 1 & \multirow{2}{*}{ SMK Negeri 1 Amuntai } & Multimedia & 47,62 & (Baik) \\
2 & & Teknik Komputer Jaringan & 43,55 & (Baik) \\
\hline 3 & \multirow{2}{*}{ SMK Negeri 3 Amuntai } & Rekayasa Perangkat Lunak & 44,09 & (Baik) \\
4 & & Animasi & 39,77 & (Tidak Baik) \\
\hline & Rerata & & $\mathbf{4 5 , 6 0}$ & (Baik) \\
\hline
\end{tabular}

Berdasarkan tabel di atas, hasil angket respon peserta didik terhadap kegiatan pembelajaran kelompok produktif pada keempat kompetensi keahlian di SMK Negeri 1 Amuntai dan SMK Negeri 3 Amuntai secara keseluruhan berada pada kategori baik dengan perolehan skor rerata sebesar 45,60. Dari data tersebut menunjukkan kegiatan pembelajaran mendapat respon yang baik dari peserta didik.

Berikut gambaran distribusi frekuensi dan kategori ideal skor angket respon peserta didik terhadap kegiatan pembelajaran pada keempat kompetensi keahlian di SMK Negeri 1 Amuntai dan SMK Negeri 3 Amuntai.

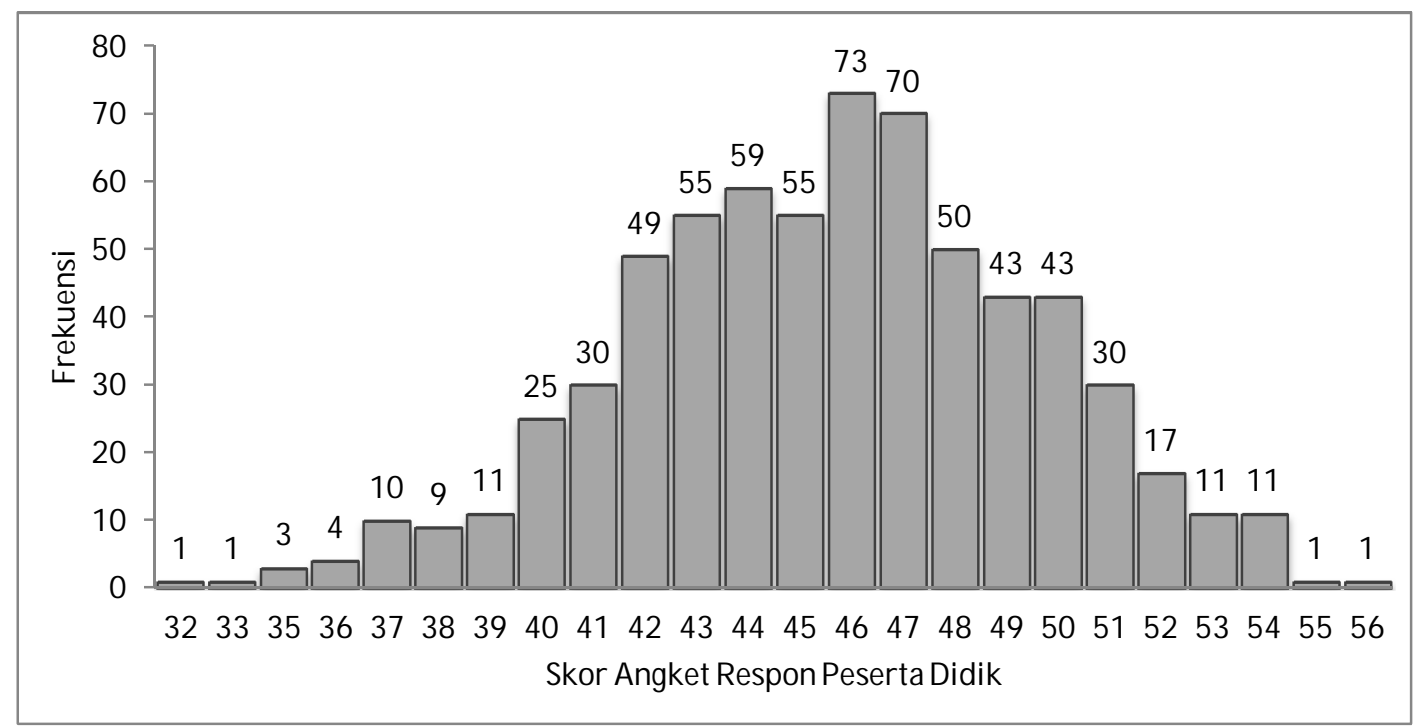

Gambar 7. Histogram Distribusi Frekuensi Respon Peserta Didik terhadap Kegiatan Pembelajaran 
Berdasarkan data distribusi frekuensi pada gambar di atas, skor angket respon peserta didik terhadap kegiatan pembelajaran pada keempat kompetensi keahlian di SMK Negeri 1 Amuntai dan SMK Negeri 3 Amuntai dapat dikelompokkan dalam kategori berikut.

Tabel 8. Kategori Ideal Skor Angket Respon Peserta didik terhadap Kegiatan Pembelajaran

\begin{tabular}{|c|c|c|c|c|}
\hline No & Kategori & Skor & Frek. Absolut & Frek. Relatif (\%) \\
\hline 1 & Sangat Baik & $X \geq 21$ & 207 & 31,27 \\
\hline 2 & Baik & $21>X \geq 17,50$ & 416 & 62,84 \\
\hline 3 & Tidak Baik & $17,50>X \geq 14$ & 39 & 5,89 \\
\hline 4 & Sangat Tidak Baik & $X<14$ & - & - \\
\hline \multicolumn{3}{|c|}{ Jumlah } & 662 & 100 \\
\hline
\end{tabular}

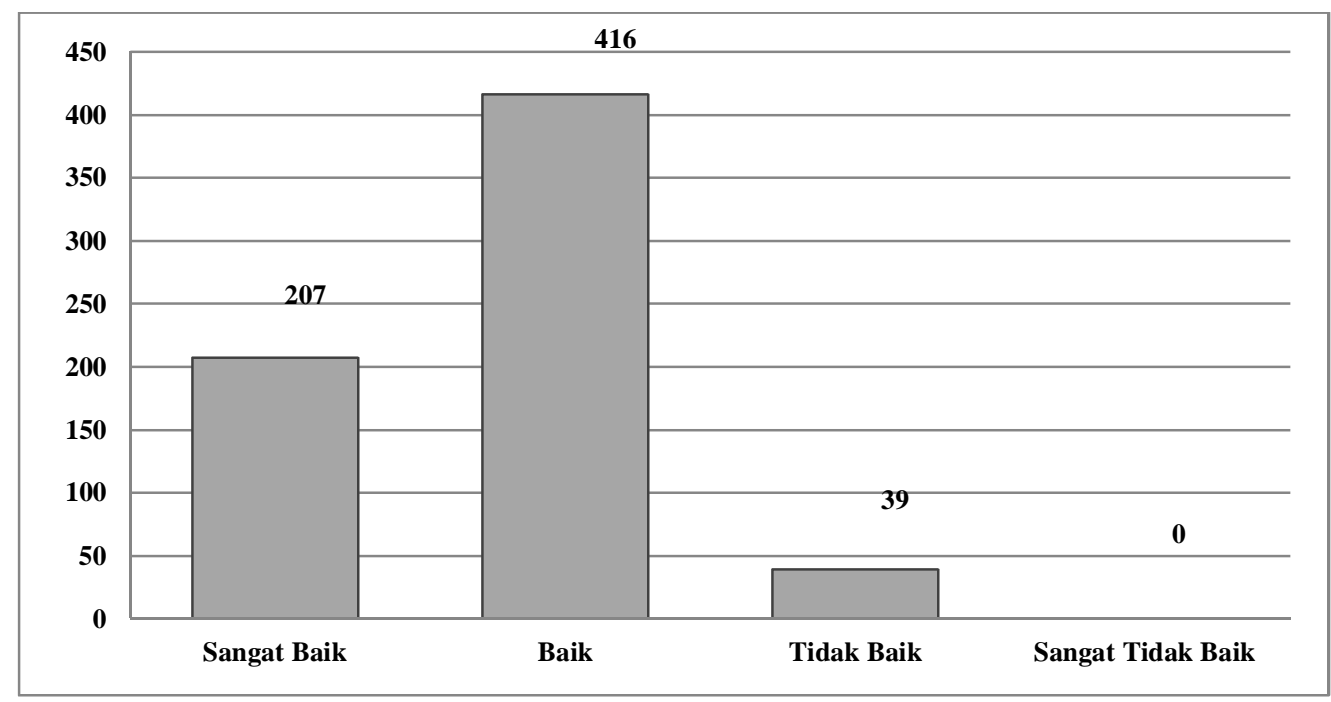

Gambar 8. Histogram Proporsi Skor Angket Respon Peserta Didik terhadap Kegiatan Pembelajaran

Berdasarkan tabel 8, menunjukkan bahwa proporsi skor hasil angket respon peserta didik terhadap kegiatan pembelajaran kelompok produktif yang berkategori sangat baik sebanyak 207 responden $(31,27 \%), 416$ responden $(62,84 \%)$ berkategori baik, 39 responden $(5,89 \%)$ berada pada kategori tidak baik. Sementara tidak ada satupun hasil angket respon peserta didik terhadap kegiatan pembelajaran
(0\%) yang memiliki skor berkategori sangat tidak baik.

Data hasil belajar peserta didik pada keempat kompetensi keahlian di SMK Negeri 1 Amuntai dan SMK Negeri 3 Amuntai dalam kaitannya dengan penelitian ini adalah nilai tengah semester genap tahun pelajaran 2011/2012. Rangkuman data ketuntasan hasil belajar peserta didik disajikan dalam tabel berikut. 
Tabel 9. Rangkuman Ketuntasan Hasil Belajar Peserta Didik

\begin{tabular}{|c|c|c|c|c|c|}
\hline \multirow[b]{2}{*}{ No } & \multirow[b]{2}{*}{ Sekolah } & \multirow{2}{*}{$\begin{array}{c}\text { Kompetensi } \\
\text { Keahlian }\end{array}$} & \multirow{2}{*}{$\begin{array}{c}\text { Jumlah } \\
\text { Peserta } \\
\text { Didik }\end{array}$} & \multicolumn{2}{|c|}{ KKM (70) } \\
\hline & & & & Tuntas & $\begin{array}{c}\text { Tidak } \\
\text { Tuntas }\end{array}$ \\
\hline 1 & \multirow{2}{*}{ SMKN 1 Amuntai } & Multimedia & 340 & 329 & 11 \\
\hline 2 & & Teknik Komputer Jaringan & 196 & 188 & 8 \\
\hline 3 & \multirow{2}{*}{ SMKN 3 Amuntai } & Rekayasa Perangkat Lunak & 104 & 99 & 5 \\
\hline 4 & & Animasi & 22 & 19 & 3 \\
\hline \multicolumn{3}{|c|}{ Jumlah } & 662 & 635 & 27 \\
\hline
\end{tabular}

Berikut gambaran distribusi frekuensi dan kriteria ketuntasan belajar peserta didik pada keempat kompetensi keahlian di SMK Negeri 1 Amuntai dan SMK Negeri 3 Amuntai.

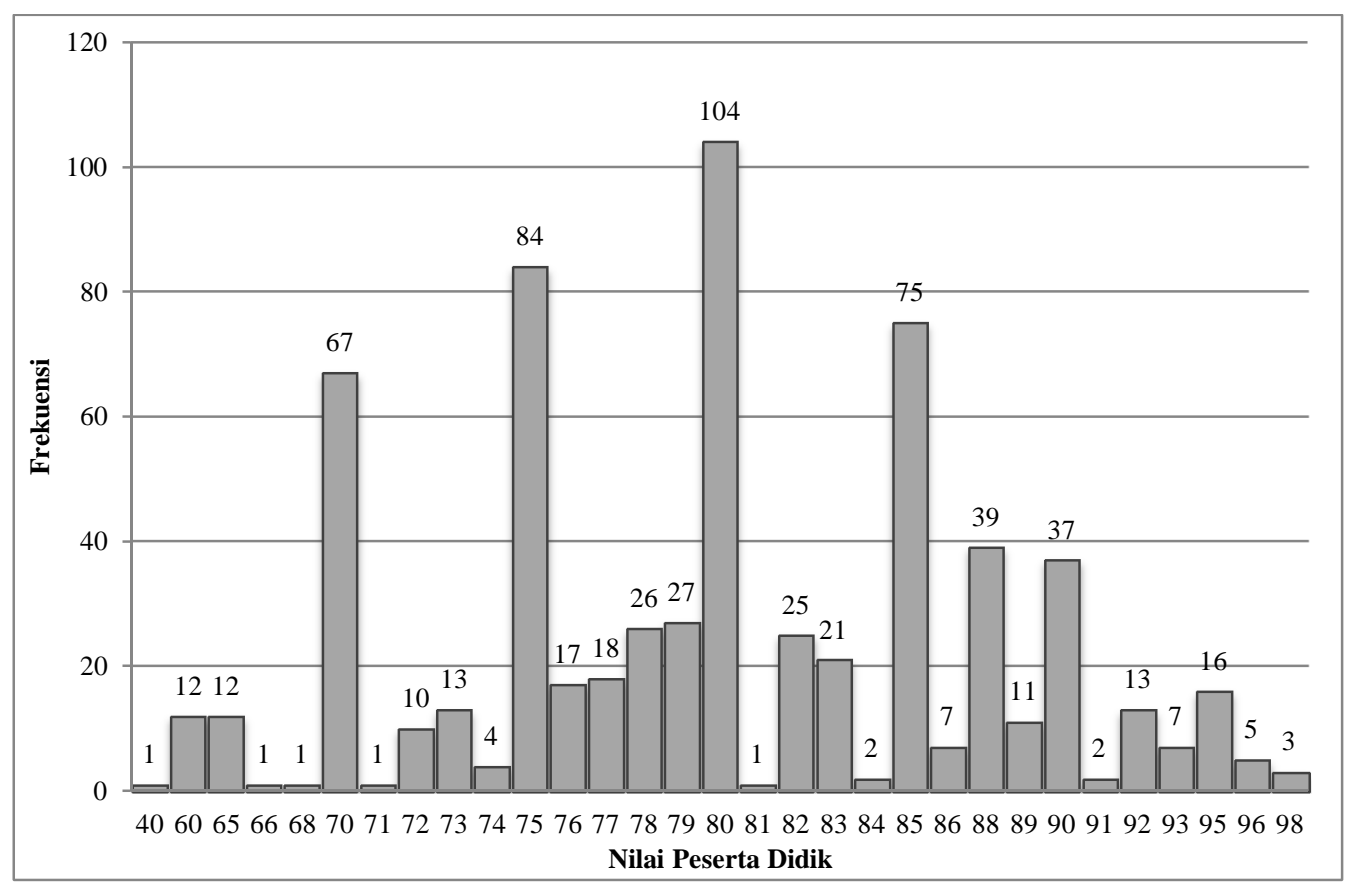

Gambar 9. Histogram Distribusi Frekuensi Ketuntasan Hasil Belajar Peserta Didik

Berdasarkan data distribusi frekuensi pada gambar 9 di atas, kriteria ketuntasan hasil belajar peserta didik pada keempat kompetensi keahlian di SMK Negeri 1 Amuntai dan SMK Negeri 3 Amuntai dapat dikelompokkan dalam kriteria berikut.

Tabel 10. Kriteria Ketuntasan Hasil Belajar Peserta Didik

\begin{tabular}{ccccc}
\hline \hline No & Kriteria & Nilai & Frekuensi Absolut & Frekuensi Relatif (\%) \\
\hline \hline 1 & Tuntas & $X \geq 70$ & 635 & 95,92 \\
2 & Tidak Tuntas & $X<70$ & 27 & 4,08 \\
\hline & Jumlah & 662 & 100 \\
\hline
\end{tabular}




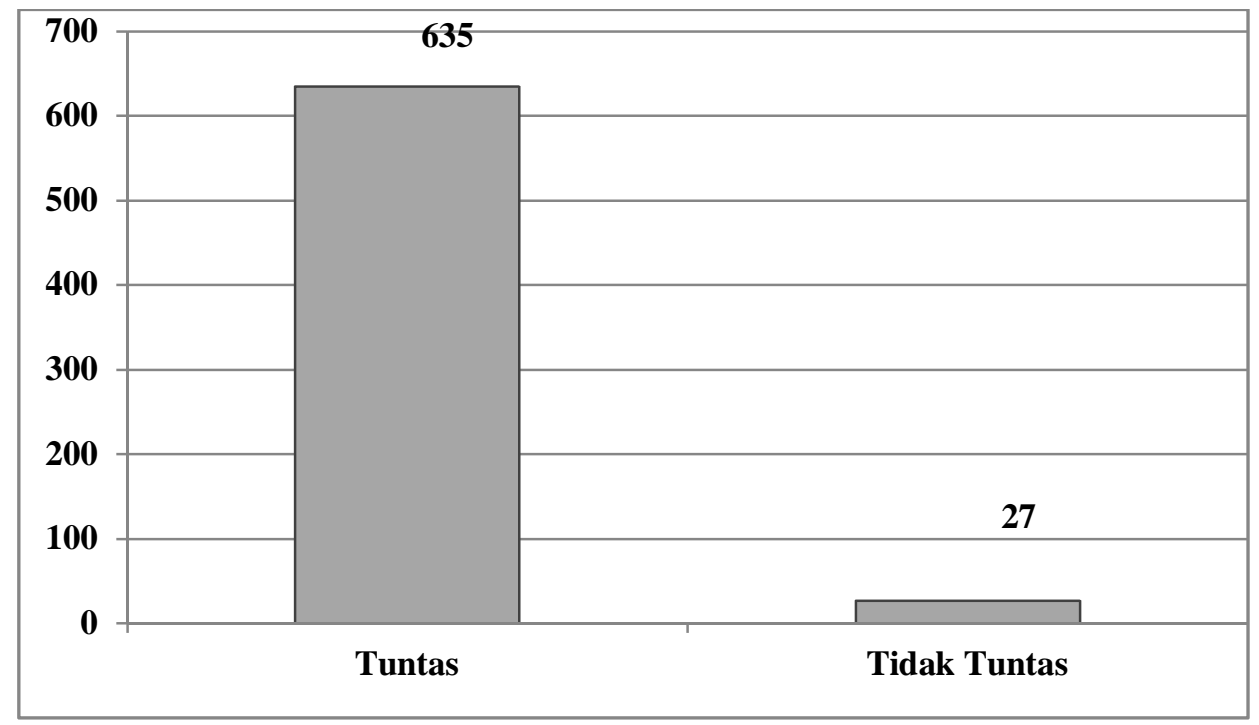

Gambar 10. Histogram Proporsi Kriteria Ketuntasan Hasil Belajar Peserta Didik

Berdasarkan data pada tabel 10, menunjukkan bahwa proporsi ketuntasan hasil belajar peserta didik kelompok produktif pada keempat kompetensi keahlian di SMK Negeri 1 Amuntai dan SMK Negeri 3 Amuntai yang berkriteria tuntas sebanyak 635 orang $(95,92 \%)$, sementara yang berkriteria tidak tuntas sebanyak 27 orang $(4,08 \%)$.

\section{KESIMPULAN}

Berdasarkan hasil analisis data dan pembahasan dapat ditarik kesimpulan bahwa pembelajaran kelompok produktif program studi teknik komputer dan informatika yang menerapkan KTSP sudah efektif. Secara rinci kesimpulan itu dirumuskan sebagai berikut

1. Hasil telaah kelengkapan dan kesesuaian perangkat perencanaan pembelajaran pada keempat kompetensi keahlian di SMK Negeri Kabupaten Hulu Sungai Utara baik silabus maupun RPP yang dikembangkan oleh guru produktif berada pada kategori baik dengan total skor 46,21. Penyususnan dan pengembangan perangkat perencanaan tersebut sudah mengacu pada standar isi (standar kompetensi dan kompetensi dasar), standar kompetensi lulusan dan sudah sesuai dengan langkah-langkah maupun format KTSP. Namun perlu perbaikan pada aspek pengidentifikasian materi pembelajaran untuk menunjang pencapaian standar kompetensi dan kompetensi dasar, perumusan pengalaman belajar, perumusan indikator pencapaian kompetensi, dan bentuk penilaian yang akan digunakan untuk melihat sejauh mana pencapaian kompetensi oleh peserta didik.

2. Hasil observasi proses pembelajaran mata pelajaran produktif program studi teknik komputer dan informatika di SMK Negeri Kabupaten Hulu Sungai Utara berada pada kategori baik, hal tersebut didukung dengan perolehan skor angket respon guru terhadap proses pembelajaran yang berada pada kategori sangat baik. Hasil observasi menunjukkan bahwa proses pembelajaran pada mata pelajaran produktif bisa dikatakan telah sesuai dengan langkah- 
langkah yang ada pada standar proses. Namun masih dapat ditingkatkan pada aspek penerapan materi terhadap kehidupan sehari-hari dengan memberikan contohcontoh yang mudah dipahami oleh peserta didik, tanggapan/jawaban terhadap pertanyaan peserta didik, dan pembuatan rangkuman materi pembelajaran yang melibatkan peserta didik sebagai penguatan atas materi yang telah disampaikan.

3. Hasil observasi penilaian pembelajaran kelompok produktif program studi teknik komputer dan informatika di SMK Negeri Kabupaten Hulu Sungai Utara berada pada kategori tidak baik. Namun masih dapat ditingkatkan dengan melakukan pengayaan terhadap penilaian yang diperoleh peserta didik, persiapan instrumen penilaian, dan pengembalian hasil pekerjaan kepada peserta didik.

4. Hasil respon peserta didik terhadap kegiatan pembelajaran kelompok produktif program studi teknik komputer dan informatika di SMK Negeri Kabupaten Hulu Sungai Utara berada pada kategori baik walaupun masih dapat ditingkatkan pada aspek penilaian hasil belajar dan pengembalian hasil pekerjaan peserta didik agar peserta didik mengetahui kemampuannya dan lebih termotivasi dalam meningkatkan prestasi belajarnya.

5. Hasil belajar peserta didik kelompok produktif program studi teknik komputer dan informatika di SMK Negeri Kabupaten Hulu Sungai Utara dapat dikatakan berhasil dan efektif dengan prosentase ketuntasan belajar aspek kognitif sebesar 96\%. Dengan hasil belajar tersebut mengindikasikan bahwa kegiatan pembelajaran yang dilakukan pada keempat kompetensi keahlian untuk rentang waktu tengah semester telah memenuhi syarat kriteria keberhasilan pembelajaran yaitu setidaktidaknya minimal $75 \%$ peserta didik telah tuntas dalam belajarnya.

\section{SARAN}

Walaupun hasil penelitian secara keseluruhan menunjukkan keberhasilan dan efektif, namun masih ada hal yang perlu ditingkatkan pada beberapa aspek sehingga perlu disarankan.

1. Bagi guru produktif pada program studi teknik komputer dan informatika. Bahwa dalam menyusun dan mengembangkan perangkat perencanaan pembelajaran harus memperhatikan dan memperbaiki aspek pengidentifikasian materi pembelajaran untuk menunjang pencapaian standar kompetensi dan kompetensi dasar, perumusan pengalaman belajar, perumusan indikator pencapaian kompetensi, dan bentuk penilaian yang akan digunakan. Dalam proses pembelajaran perlu adanya peningkatan pada aspek penerapan materi terhadap kehidupan sehari-hari dengan memberikan contoh-contoh yang kongkrit dan mudah dipahami oleh peserta didik. Tanggapan/jawaban terhadap pertanyaan peserta didik secara jelas, pembuatan rangkuman materi pembelajaran yang melibatkan peserta didik sebagai penguatan atas materi yang telah disampaikan, serta pengembangan format penilaian yang akan digunakan untuk mengukur kemampuan peserta didik. 
2. Bagi sekolah. Perlu terus mendukung guruguru produktif dalam mengembangkan dan merevisi perangkat perencanaan maupun proses pembelajaran melalui pemenuhan fasilitas yang dibutuhkan dalam kegiatan pembelajaran. Dengan demikian diharapkan motivasi guru akan terbentuk secara utuh dalam usaha meningkatkan mutu pembelajaran.

3. Bagi Dinas Pendidikan dan Kebudayaan Kabupaten Hulu Sungai Utara. Perlu untuk dilakukannya monitoring dan evaluasi secara berkala terhadap kelompok produktif pada kegiatan pembelajaran yang meliputi aspek perencanaan, proses, dan penilaian hasil belajar. Dengan demikian diharapkan mutu pendidikan secara keseluruhan di tingkat Kabupaten dapat meningkat dan lebih baik dari sebelumnya.

4. Bagi peneliti selanjutnya dimungkinkan untuk dapat melakukan penelitian sejenis terhadap populasi yang mencakup seluruh kompetensi keahlian di Kabupaten Hulu Sungai Utara.

\section{DAFTAR PUSTAKA}

Depdiknas. (2006). Lampiran Peraturan Menteri Pendidikan Nasional RI Nomor 22 Tahun 2006 tentang Standar Isi Untuk Satuan Pendidikan Dasar dan Menengah.

Djemari Mardapi. (2008). Teknik penyusunan instrumen tes dan nontes. Yogyakarta: Mitra Cendekia Press.

Enco Mulyasa. (2010). Kurikulum berbasis kompetensi, konsep, karakteristik, dan implementasi. Bandung: Remaja Rosda Karya.

Gough, S. (2010). Technical and vocational education and training an investmentbased approach. London: Continuum International Publishing Group.

Null. W. (2011). Curriculum from theory to practice. Maryland: Rowman \& Littlefield Publishers, Inc.

Oliva, P, F. (2005). Developing the Curriculum. Boston: Pearson Education, Inc.

Pavlova, M. (2009). Technology and vocational education for ssustainable development empowering individuals for the future. Bonn: Springer Science Business Media.

Russell, M. K., \& Airasian, P. W. (2012). Classroom assessment, concepts and applications $\quad\left(7^{\text {th }}\right.$ ed). New York: McGraw-Hill. 